\title{
Pengembangan Multimedia Interaktif dengan Metode EPIC 5C berbasis Model Case-Based Learning pada Materi Tematik Terpadu Kelas V
}

\author{
Budi Kurniawan ${ }^{*}$, Ivo Basri K.2, Ni Putu Kusuma Widiastuti3 ${ }^{3}$ Rizgy A. R. Ahmad4 \\ 1,2,4 Universitas Muhammadiyah Kupang, Kota Kupang, Indonesia \\ ${ }^{3}$ Universitas Pendidikan Ganesha, Bali, Indonesia
}

\section{A R T I C L E I N F O}

\section{Article history:}

Received September 26, 2021

Revised September 28, 2021

Accepted November 20, 2021

Available online December 25, 2021

Kata Kunci:

Modul, Project Based Learning, Efektivitas

Keywords:

Modules, Project Based Learning, Effectiveness

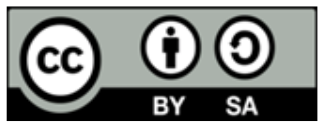

This is an open access article under the CC BY-SA license.

Copyright $(2021$ by Author. Published by Universitas Pendidikan Ganesha.

\begin{abstract}
A B S T R A K
Belum tersedianya modul yang sistematis pada mata kuliah Kewirausahaan di Program Studi Teknik Fabrikasi dan Pengelasan Logam (TFPL) serta hasil belajar peserta didik belum optimal. Penelitian ini bertujuan untuk mengembangkan modul pembelajaran dan menghasilkan modul yang valid, praktis, dan efektif pada mata kuliah Kewirausahaan berbasis proyek untuk peserta didik Program Studi TFPL di Akademi Komunitas Negeri Pesisir Selatan. Penelitian ini menggunakan metode Research and Development (penelitian dan pengembangan), dengan model pengembangan 4D. Prosedur pengembangan 4D yaitu Define (pendefinisian), Design (Perancangan), Develop (Pengembangan) dan Disseminate (Penyebaran). Teknik analisis data efektivitas dengan memakai skor $\mathrm{N}$-Gain. Hasil yang diperoleh dari penelitian pengembangan ini untuk efektivitas modul pembelajaran diperoleh dari nilai pretest dan posttest mahasiswa setelah menggunakan modul pembelajaran berada dalam kategori efektif. Kesimpulannya, modul pembelajaran berbasis proyek yang dikembangkan dapat digunakan pada proses pembelajaran untuk meningkatkan hasil belajar peserta didik.
\end{abstract}

\begin{abstract}
A B S TRACT
The motion system material in humans is interesting for students, but this material is difficult to reach. Learners have not fully implemented the benefits of learning the motion system material in humans. It affects the low student learning outcomes. This study aims to produce visual learning media using Canva on Motion System materials. 2 experts and 1 teacher validated visual learning media to test its practicality. The methods used to collect data are observation, interviews, and questionnaires. The instrument used to collect data is a questionnaire. The technique used in data analysis is descriptive qualitative and quantitative analysis. As a result, visual learning media using Canva has been developed using 3 stages of the IDI model, namely the define stage, which aims to get an overview of conditions in the field by distributing student response questionnaires and teacher interviews, the development stage by designing visual learning media using Canva and validated by experts (validators). The evaluation phase aims to determine the extent of the benefits, convenience, and time efficiency of using media by teachers and students. The validity value is $89.68 \%$ with valid criteria, practicality by teachers is $91.87 \%$ with very valid criteria, and students with very valid criteria $90.06 \%$. The results of the study show that the video learning media using Canva is valid and practical for learning.
\end{abstract}

\section{PENDAHULUAN}

Merebaknya pandemi Covid-19 di seluruh dunia termasuk di Indonesia memberikan dampak besar terhadap berbagai aktivitas manusia, tak terkecuali aktivitas pendidikan dan kegiatan pembelajaran di sekolah. Untuk mengatasi penyebaran virus covid-19 di bidang pendidikan, pelaksanaan pembelajaran yang awalnya dilaksanakan di sekolah melalui proses tatap muka langsung antara guru dan siswa dihentikan sementara dan digantikan dengan kegiatan belajar di rumah menggunakan model

*Corresponding author.

E-mail addresses: kurniawanbudi012@gmail.com (Budi Kurniawan) 
pembelajaran daring (Baharuddin, 2020; Pujowati, 2021; Yunitasari \& Hanifah, 2020). Pembelajaran daring merupakan salah satu bentuk inovasi pembelajaran di masa pandemic covid-19 seperti saat ini. Dalam pembelajaran daring guru dan siswa dapat belajar dari rumah dan dengan waktu yang bersamaan (Telaumbanua, 2021). Kegiatan pembelajaran daring sangat sesuai dengan perkembangan teknologi digital di era globalisasi saat ini. Melalui pembelajaran daring, guru dan siswa dibiasakan menggunakan berbagai macam teknologi yang dapat diterapkan dalam bidang pendidikan, sehingga guru dan siswa lebih melek terhadap perkembangan teknologi (Aini, 2021; Alami, 2020).

Pembelajaran daring memberikan tantangan tersendiri bagi guru dan siswa. Dalam kegiatan pembelajaran daring, siswa dituntut untuk belajar secara aktif dan mandiri dengan cara mencari berbagai materi pelajaran melalui internet. Dengan cara tersebut siswa akan dapat merekonstruksi pengetahuannya sendiri (Nugraha et al., 2020; Wibawa, 2021). Selain menuntut peran akttif siswa pembelajaran daring, juga menentut peran aktif guru sebagai tenaga pendidik. Guru dituntut agar mampu melaksanakan proses pembelajaran secara aktif, melaksanakan pembelajaran dengan menggunakan model pembelajaran yang tepat, serta mengembangkan berbagai media pembelajaran yang dapat membantu proses pembelajaran siswa di tengah keterbatasan yang ada (Satrianingrum \& Prasetyo, 2020; Subakti \& Handayani, 2021). Media pembelajaran menjadi salah satu komponen penting dalam pembelajaran daring. Media pembelajaran dapat membantu guru dalam menyampaikan materi ajar, sehingga siswa dapat menerima materi tersebut dengan baik (Salsabila et al., 2020).

Hanya saja kenyataannya di lapangan menunjukkan bahwa penggunaan media dalam proses pembelajaran daring masih sangat kurang (Anugrahana, 2020; Harahap et al., 2021). Dalam kegiatan pembelajaran daring, guru cenderung hanya mengirim tugas melalui group whatsapp tanpa memberikan pemaparan materi kepada siswa (Asmuni, 2020). Dilaksanakannya proses pembelajaran yang demikian karena kurangnya kemampuan guru mengembangkan suatu media yang layak digunakan dalam pembelajaran daring, sehingga proses pembelajaran terkesan monoton dan membosankan bagi siswa. Kegiatan pembelajaran yang hanya dilakukan dengan memberikan tugas kepada siswa berdampak pada rendahnya tingkat pemahaman siswa terhadap materi yang dipelajari selama proses pembelajaran daring. Hal seperti ini juga berdampak pada penurunan hasil belajar siswa. Untuk mengatasi permasalahan tersebut, guru membutuhkan suatu media pembelajaran yang tepat, efektif, dan efisien.

Salah satu media pembelajaran yang dapat digunakan untuk menunjang proses pembelajaran daring adalah multimedia interaktif. Multimedia interaktif merupakan salah satu solusi efektif dalam menampilkan pembelajaran inovatif dan pembelajaran bermakna (meaningful learning) sehingga proses pembelajaran tetap terlaksana dengan baik, praktis, dan berkualitas (Kurniawati \& Nita, 2018). Dalam multimedia interaktif materi pembelajaran disajikan dalam kombinasi teks, suara, animasi, dan video yang disampaikan kepada peserta didik dengan memanfaatkan komputer atau peralatan manipulasi elektronik dan digital yang lain (Widyatmojo \& Muhtadi, 2017). Melalui gabungan media-media ini pengalaman belajar akan lebih bermakna dan mencerminkan suatu pengalaman dalam kehidupan seharihari (Fathimah \& Ishartiwi, 2018).

Pengembangan multimedia interaktif dapat dilakukan dengan menggunakan menggunakan metode EPIC 5C. EPIC (education, playful, inovation dan confident) merupakan komponen yang harus ada dalam sebuah media pembelajaran. Education, playful, inovation dan confident dalam pengembangan media mengandung makna bahwa media yang dikembangkan harus mampu memberikan penyajian materi yang baik, menyenangkan, inovatif, dan percaya diri (Pancaningrum \& Sari, 2020). Dengan memiliki kelima komponen tersebut, media yang dikembangkan akan dapat menarik minat siswa untuk belajar dan dapat membantu proses belajar siswa. Siswa akan memiliki kemampuan critical thinking, communication, collaboration, creativity, dan character (5C) dalam setiap kegiatan pembelajarannya.

Selain dapat dikembangkan dengan menggunakan metode EPIC 5C, multimedia interaktif juga dapat dikembangkan dengan menggunakan model Case Based Learning (CBL). CBL merupakan pembelajaran berbasis kasus menjadi metode yang bisa diterapkan pada proses pembelajaran (Nurhusain \& Hadi, 2021). CBL sendiri merupakan teknik pembelajaran yang berpusat pada pengembangan potensi peserta didik dalam menganalisis suatu kasus dan memberikan pemecahan masalah terhadap kasus tersebut terhadap pemahaman konsep peserta didik (Ichsan et al., 2018). Kegiatan pembelajaran yang dilakukan dengan menggunakan metode CBL yang disertai dengan umpan balik berpengaruh terhadap pemahaman konsep siswa . Model CBL dapat dikombinasikan dengan penggunaan multimedia interaktif dengan menyajikan informasi yang terdiri dari teks, suara, grafik, animasi, dan video.

Beberapa penelitian yang telah dilakukan sebelumnya menyebutkan bahwa bahwa multimedia interaktif berbasis pendekatan sets untuk meningkatkan kemampuan berpikir kritis siswa kelas IV sekolah dasar telah valid, praktis, dan efektif (Firdaus et al., 2020). Penelitian lainnya juga mengungkapkan hal serupa yakni penggunaan multimedia interaktif berpengaruh terhadap keterampilan berpikir kritis siswa tingkat SMA (Husein et al., 2017). Penelitian selanjutnya juga menyebutkan bahwa 
kepraktisan penggunaan multimedia interaktif dalam pembelajaran tematik kelas IV termasuk dalam kriteria sangat praktis untuk digunakan dalam proses pembelajaran (Kumalasani, 2018). Berdasarkan beberapa penelitian tersebut dapat dikatakan bahwa penggunaan multimedia interaktif dalam kegiatan pembelajaran dapat meningkatkan kreativitas belajar siswa. Hanya saja pada penelitian sebelumnya belum terdapat kajian yang membahas mengenai pengembangan multimedia interaktif dengan metode EPIC 5C yang dipadukan model case-based learning materi tematik terpadu pada peserta didik kelas V. Oleh karena itu, penelitian ini difokuskan pada pengembangan tersebut dengan tujuan untuk mengetahui validitas multimedia interaktif berbasis metode EPIC 5C dan model case base learning.

\section{METODE}

Penelitian ini merupakan penelitian pengembangan yang dikembangkan dengan menggunakan model pengembangan 4D. Model pengembangan 4D terdiri dari fase Define (pendefinisian), Design (perancangan), Develop (pengembangan), dan Disseminate (penyebaran). Subjek yang terlibat dalam penelitian ini yakni siswa kelas $\mathrm{V}$ sekolah dasar. Pengumpulan data dalam penelitian dilakukan dengan menggunakan metode observasi, wawancara, dan penyebaran angket penelitian. Adapun intrumen yang digunakan dalam penelitian ini yakni instrumen kriteria kevalidan, kepraktisan, dan reliabilitas. Analisis data hasil penelitian dilakukan dengan Uji User Experience (UE) dan User Interface (UI) diukur dengan kinerja usability diukur menggunakan pengujian poststudy dengan metode System Usability Scale (SUS). Hasil pengujian validitas kemudian dihitung persentasenya dengan menggunakan rumus persentase yang kemudian diklasifikasikan ke dalam tabel kriteria validitas dan efektivitas.

\section{HASIL DAN PEMBAHASAN}

\section{Hasil}

Pengembangan multimedai interaktif berbantuan metode EPIC 5C dan model pembelajaran case base learning dilakukan dengan tujuan untuk mengetahui kevalidan multimedia tersebut. Pengembangan medai dilakukan dalam 4 tahapan pengembangan. Hasil dari tiap-tiap tahapan pengembangan adalah sebagai berikut. Tahap pengembangan yang pertama yakni tahap define (pendefinisian). Tahap pendefinisian dilakukan dengan menganalisis kebutuhan peserta didik, menganalisis materi, analisis tugas dan penilaian. serta spesifikasi produk. Analisis peserta didik dilaksanakan untuk menelaah tentang karakteristik peserta didik. sebagai bahan pertimbangan, untuk mengembangkan Multimedia Interaktif dengan Metode EPIC 5C Tema Ekosistem mencakup: jumlah peserta didik, latar belakang tingkat kognitif, dan latar belakang kondisi sosial. Selanjutnya, analisis materi dilakukan untuk mengetahui jenis pembelajaran tematik integratif yang dilaksanakan pada Tema Ekosistem berdasarkan Kompetensi Inti (KI) dan KD (Kompetensi Dasar) dalam kurikulum.

Analisis tugas dan penilaian dilakukan untuk mendpatkan informasi mengenai pemahaman dan pengetahuan peserta didik pada Tema Ekosistem serta dilakukan untuk memberikan informasi mengenai kemampuan peserta didik dalam mengaplikasikan pengetahuan dan media yang telah diterimanya. Setelah melakukan penjabaran kompetensi dasar ke dalam indikator yang lebih spesifik dan disesuaikan dengan hasil analisis materi dan analisis tugas dengan Tema Ekosistem yang dilakukan sebelumnya, maka produk yang akan dibuat yakni buku pedoman yang dikembangkan berisi konten media pembelajaran. Multimedia interaktif dengan metode EPIC 5C yang meliputi lembar kerja peserta didik (LKPD), puzzle, flipchart, leaflet, sketsa, dan video pembelajaran Multimedia Interaktif dengan Metode EPIC 5C.

Tahap pengembangan yang kedua yakni tahap perancangan (design). Pada tahap perancangan dilakukan penyusunan desain media, pemilihan media, serta pemilihan format media. Penyusunan desain media dimulai dengan tujuan, menentukan hal-hal yang perlu diketahui oleh para peserta didik, dan menggambarkan proses yang dilalui peserta didik dapat menggunakan media pembelajaran. Media yang digunakan pada kegiatan proses pembelajaran berupa LKPD, puzzle, leaflet, dan video pembelajaran, yang memiliki banyak warna dengan gambar-gambar animasi/kartun dan kata-kata menarik, sehingga memudahkan peserta didik untuk memahami Tema Ekosistem menggunakan metode pembelajaran EPIC 5C berbasis Model CBL. Pemilihan format dilaksanakan dengan mengkaji format perangkat dan instrumen pembelajaran dengan menggunakan multimedia interaktif dengan metode EPIC 5C berbasis CBL yang dikembangkan, sebagai berikut.

Pada tahap design juga dilakukan perancangan Instrumen penelitian untuk mengetahui kualitas multimedia interaktif metode EPIC 5C berbasis CBL. Instrumen kevalidan meliputi format validasi kelayakan dan validasi kepraktisan. Instrumen kelayakan yang dihasilkan pada tahap rancangan ini meliputi kelayakan pedoman pembuatan multimedia interaktif metode EPIC 5C berbasis CBL dan kelayakan LKPD dengan metode EPIC 5 C berbasis CBL, dan kelayakan seluruh media yang tercantum 
dalam buku pedoman, meliputi: puzzle, leaflet, dan video pembelajaran. Sedangkan instrumen kepraktisan yang dihasilkan pada tahap rancangan ini, meliputi lembar angket respon guru dan lembar angket respon peserta didik. Aspek yang dinilai adalah relevansi aspek penilaian dengan dengan deskriptor (butir pertanyaan/pernyataan (konstruksi yang berisi pertanyaann/ pernyataan yang direspon guru dan peserta didik. Jumlah keseluruhan untuk angket respon guru 20 item dan angket respon peserta didik 10 item.

Tahap penelitian yang ketiga yakni tahap pengembangan produk multimedia interaktif. Tahap ini bertujuan untuk menghasilkan prototype-2 atau perangkat, instrumen, dan media pembelajaran yang sudah direvisi berdasarkan masukan dari validator. Tahap ini meliputi validasi perangkat oleh para validator diikuti dengan revisi, simulasi yaitu kegiatan mengoperasionalkan rencana pengajaran, dan uji coba terbatas dengan peserta didik sesungguhnya. Langkah berikutnya adalah uji coba lebih lanjut dengan peserta didik yang sesuai dengan kelas sesungguhnya. Namun, terlebih dahulu dilakukan uji keterbacaan kepada beberapa peserta didik dan guru, teman sejawat yang dipilih untuk melihat tampilan media pembelajaran berupa puzzle, flipchart, leaflet, sketsa, dan video pembelajaran dapat terbaca dengan jelas dan mudah dipahami.

Kegiatan validasi dilakukan dengan memberikan hasil rancangan pedoman, LKPD, dan multimedia interaktif metode EPIC 5C berbasis CBL dan lembar instrumen berupa lembar validasi, yang divalidasi oleh dua orang validator. Penilaian yang diberikan oleh kedua validator telah dihitung tingkat kevalidannya berdasarkan rumus validitas isi Greogory. Berdasarkan nilai validasi isi dapat disimpulkan bahwa kevalidan yaitu $\mathrm{V}=1$ atau $\mathrm{V}=100 \%$. Hal ini berarti hasil penilaian dari kedua Validator memiliki "relevansi kuat" dengan koefisien validitas isi lebih dari $75 \%$ atau $\mathrm{V}>75 \%$.

Hasil validasi akan menentukan kelayakan dan kepraktisan pengembangan multimedia interaktif metode EPIC 5C berbasis CBL yang digunakan dalam proses pembelajaran Tematik integratif. Adapun rata-rata persentase kelayakan dan kepraktisan disajikan pada Tabel 1, 2, dan 3

Tabel 1. Rata-Rata Persentase Kelayakan Buku Pedoman Pembuatan Multimedia Interaktif Metode EPIC 5C berbasis CBL, dan LKPD

\begin{tabular}{cclc}
\hline No & Validator & \multicolumn{1}{c}{ Kriteria Kelayakan } & Rata-Rata (Persentase) \\
\hline 1. & Validator I & $\begin{array}{l}\text { Sangat valid dapat digunakan tanpa revisi artinya } \\
\text { sangat layak }\end{array}$ & $95 \%$ \\
2. & Validator II & $\begin{array}{l}\text { Sangat valid dapat digunakan tanpa revisi artinya } \\
\text { sangat layak }\end{array}$ & $90 \%$ \\
\hline
\end{tabular}

Berdasarkan nilai validasi dari kedua validator dapat disimpulkan bahwa Buku Pedoman Pembuatan Media Interaktif dengan Metode EPIC 5C berbasis CBL dan LKPD berada dalam kategori sangat layak karena koefisien validitas yang dihasilkan $>75 \%(0,75)$ dan konsistensi internalnya juga demikian adanya (reliable), dengan rata-rata persentase kedua validator yang disajikan pada Tabel 1 , adalah 92,5\%.

Saran dari validator yakni merapikan sampul pada halaman depan Buku Pedoman dan LKPD Multimedia Interaktif dengan metode EPIC 5C berbasis CBL.

Tabel 2. Rata-Rata Persentase Kelayakan Multimedia Interaktif dengan Metode EPIC 5C Berbasis CBL Berupa Puzzle, Flipchart, Leaflet, Sketsa, dan Video Pembelajaran

\begin{tabular}{cclc}
\hline No & Validator & \multicolumn{1}{c}{ Kriteria Kelayakan } & Rata-Rata (Persentase) \\
\hline 1. & Validator I & $\begin{array}{l}\text { Sangat valid dapat digunakan tanpa revisi artinya } \\
\text { sangat layak }\end{array}$ & $89 \%$ \\
2. & Validator II & $\begin{array}{l}\text { Sangat valid dapat digunakan tanpa revisi artinya } \\
\text { sangat layak }\end{array}$ & $86 \%$ \\
\hline
\end{tabular}

Berdasarkan nilai validasi dari kedua validator dapat disimpulkan bahwa multimedia interaktif dengan metode EPIC 5C berbasis CBL berupa Puzzle, Flipchart, Leaflet, Sketsa, dan Video Pembelajaran berada dalam kategori sangat layak karena koefisien validitas yang dihasilkan $>75 \%(0,75)$ dan konsistensi internalnya juga demikian adanya (reliable) dengan rata-rata persentase kedua validator adalah 87,5\% disajikan pada Tabel 2 .

Saran dari validator yakni menyesuaikan gradasi warna pada setiap multimedia nteraktif dengan metode EPIC 5C berbasis CBL. 
Tabel 3. Rata-rata Persentase Kepraktisan Pedoman, LKPD, dan Multimedia Interaktif EPIC 5C Berbasis CBL Berdasarkan Angket Respon Guru dan Peserta Didik

\begin{tabular}{cllc}
\hline Responden & \multicolumn{1}{c}{ Aspek yang Dinilai } & Kriteria Kepraktisan & Rata-Rata (Persentase) \\
\hline \multirow{5}{*}{ Guru } & Pedoman PembuatanMultimedia Sangat valid dapat & \\
& Interaktif (puzzle, flipchart, leaflet, digunakan tanpa revisi & $90 \%$ \\
& sketsa, dan video pembelajaran & & \\
& LKPD dengan metode EPIC 5C artinya sangat praktis & & \\
& LKPD dengan metode EPIC 5C dan & & \\
& Multimedia Interaktif EPIC 5CSangat valid dapat & \\
Peserta Didik & Berbasis CBL puzzle, flipchart,digunakan tanpa revisi & $91 \%$ \\
& leaflet, sketsa, dan videoartinya sangat praktis & \\
& pembelajaran
\end{tabular}

Berdasarkan nilai validasi dari kedua responden dapat disimpulkan bahwa Pedoman, LKPD, dan Multimedia Interaktif EPIC 5C berbasis CBL berada dalam kategori sangat praktis karena koefisien validitas yang dihasilkan $>75 \%(0,75)$ dan konsistensi internalnya juga demikian adanya (reliable). Nilai rata-rata persentase kepraktisan adalah 90\% responden guru dan 91\% responden eserta didik disajikan pada Tabel 3. Adapun hasil pengembangan produk multimedia interaktif berdasarkan desain produk dan masukan dari ahli dapat dilihat pada Gambar 1 dan 2.

Tahap pengembangan yang kelima yakni tahap penyebaran (disseminate). Setelah dilakukan validasi terhadap Pembuatan Buku Pedoman, LKPD, dan Multimedia Interaktif metode EPIC 5C berbasis CBL yang telah diujicobakan, direvisi, kemudian disebarkan ke lapangan. Karena adanya pandemi Covid19, maka penyebaran produk tersebut hanya terbatas pada MIS Darul Hijrah Madani Kota Kupang. Hasil penyebaran media menunjukkan bahwa multimedia interaktif metode EPIC 5C berbasis CBL yang digunakan pada saat pembelajaran tematik integratif sangat layak dan praktis untuk digunakan/dikembangkan karena sangat memengaruhi peningkatan belajar peserta didik.

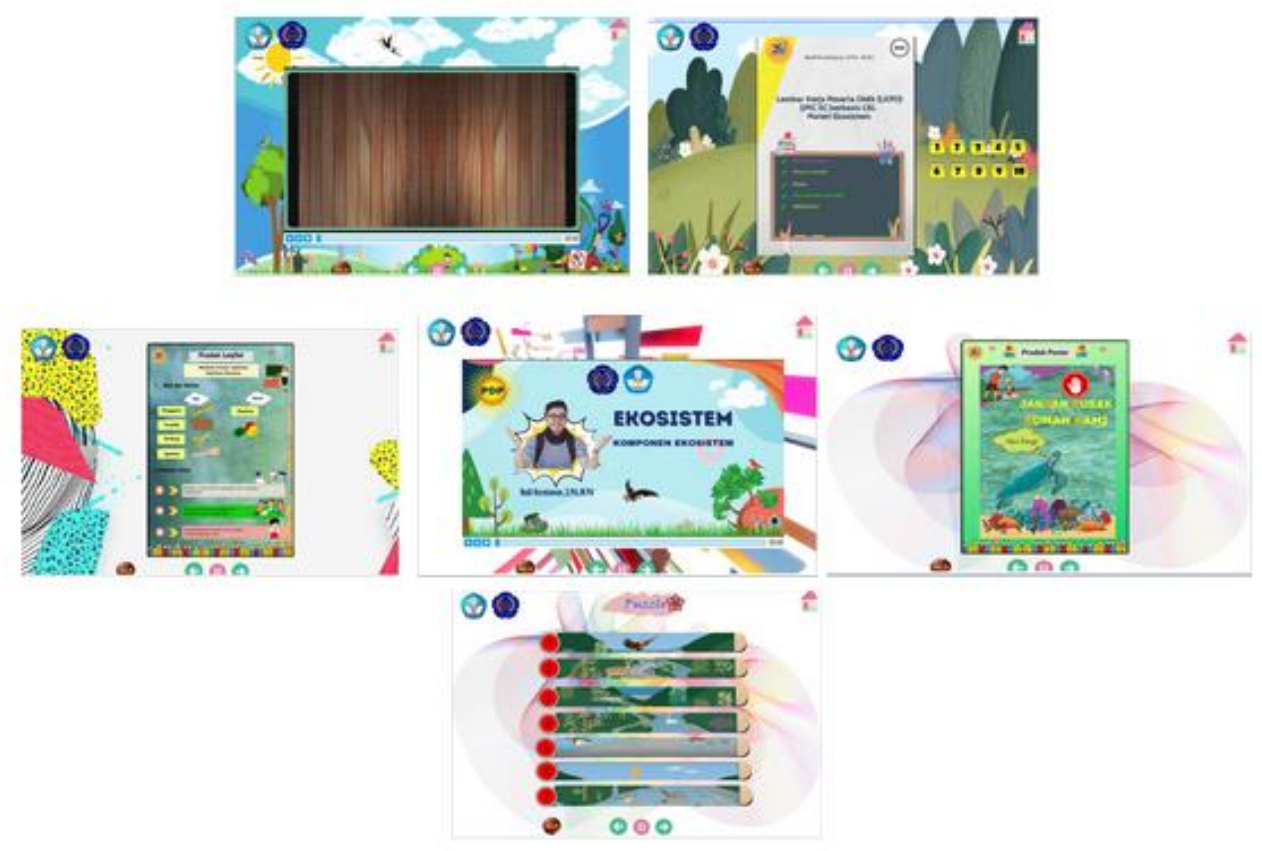

Gambar 1. Tampilan Isi Buku Pedoman Pembuatan Multimedia Interaktif 


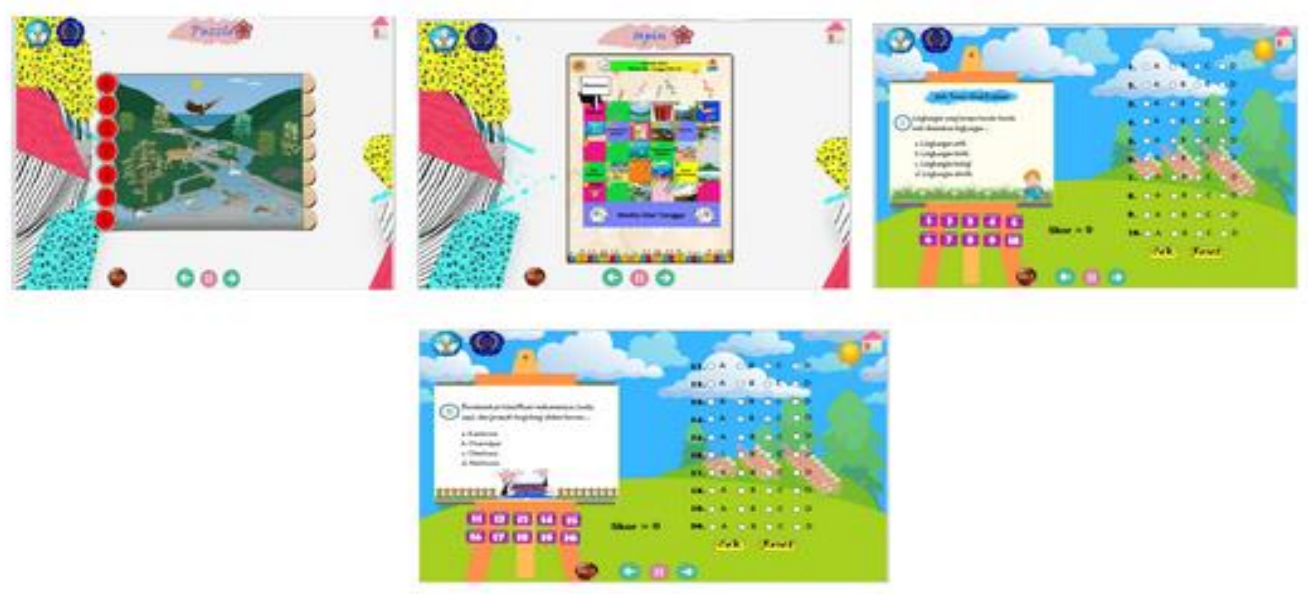

Gambar 2. Tampilan Screenshot Video Pembelajaran

\section{Pembahasan}

Penelitian pengembangan multimedai interaktif dengan menggunakan metode EPIC 5C berbasis model CBL menunjukkan hasil bahwa medai ini sangat layak dan efektif untuk dikembangkan dan dimanfaatkan oleh siswa sekolah dasar pada pembelajaran tematik. Hasil yang diperoleh pada penelitian ini tidak terlepas dari karakteristik multimedia interaktif, yakni multimedai interaktif merupakan media yang menyajikan berbagai bentuk tampilan seperti gambar, suara, vidio, dan animasi yang sangat digemari oleh siswa sekolah dasar (Kumalasani, 2018; Muin, 2017; Yuniarni et al., 2019). Selain dipengaruhi oleh karakteristik multimedia yang menarik, keberhasilan pengembangan media juga disebabkan oleh beberapa faktor. Faktor pertama yakni media yang dikembangkan sesuai dengan kebutuhan pembelajaran siswa di masa pandemi. Seperti yang telah kita ketahui bersama bahwa dalam kegiatan pembelajaran daring dilakukan dengan perantara media digital (Panditung, 2020; Priyastuti \& Suhadi, 2020), sehingga multimedia sangatlah cocok digunakan dalam kegiatan pembelajaran daring. Dalam hal ini multimedia yang dikembangkan yakni berupa LKPD yang disajikan secara digital serta vidio pembelajaran yang diunggah melalui youtobe. Media yang disajikan secara digitial akan lebih mudah untuk diakses peserta didik, selain itumedia tersebut juga dapat dilihat secara berulang-ulang dan tidak mudah hilang (Adhe, 2018; Mustakim, 2020).

Faktor pendukung keberhasilan kedua yakni media yang dikembangkan sesuai dengan karakteristik siswa sekolah dasar. Siswa sekolah dasar merupakan siswa yang berada pada tahap perkembangan operasional konkret. Pada tahap ini anak mulai mengingat sesuatu berdasarkan pada objek-objek konkret yang telah dipelajarinya (Basri, 2018; Bujuri, 2018). Melalui objek-objek itu pula peserta didik akan mulai membentuk pengetahuan yang baru dan mengembangkan berbagai kemampuan lainnya (Khaulani et al., 2020). Faktor ketiga yakni media yang dikembangkan memiliki desain, warna, gambar, serta animasi yang menarik. Gambar, warna, animasi, serta desain yang menarik dapat meningkatkan keinginan siswa untuk mempelajari media tersebut. Hal ini juga disebabkan oleh karakteristik siswa yang senang mempelajari berbagai hal-hal baru yang menarik perhatiannya.

Hasil yang diperoleh pada penelitian ini sejalan dengan hasil penelitian sebelumnya yang juga menyatakan bahwa multimedia interaktif berbasis pendekatan sets untuk meningkatkan kemampuan berpikir kritis siswa kelas IV sekolah dasar telah valid, praktis, dan efektif (Firdaus et al., 2020). Penelitian lainnya juga mengungkapkan hal serupa yakni penggunaan multimedia interaktif berpengaruh terhadap keterampilan berpikir kritis siswa tingkat SMA (Husein et al., 2017). Penelitian selanjutnya juga menyebutkan bahwa kepraktisan penggunaan multimedia interaktif dalam pembelajaran tematik kelas IV termasuk dalam kriteria sangat praktis untuk digunakan dalam proses pembelajaran (Kumalasani, 2018). Berdasarkan hasil penelitian yang didukung oleh penelitian sebelumnya dapat dikatakan bahwa multimedia interaktif dengan metode EPIC 5C berbasis CBL efektif untuk dimanfaatkan oleh siswa dalam pembelajaran. Oleh karena itu, media ini sangat layak dikembangkan. 


\section{SIMPULAN}

Simpulan yang dapat ditarik dari penelitian pengembangan ini yakni multimedia interaktif metode EPIC 5C berbasis CBL valid untuk dikembangkan dan dibelajarkan kepada siswa kelas V kususnya pada pembelajaran tematik, karena memiliki karakteristik yang praktis dan mudah digunakan.

\section{DAFTAR RUJUKAN}

Adhe, K. R. (2018). Pengembangan Media Pembelajaran Daring Matakuliah Kajian PAUD di Jurusan PG PAUD Fakultas Ilmu Pendidikan Universitas Negeri Surabaya. Journal of Early Childhood Care and Education, 1(1), 26. https://doi.org/10.26555/jecce.v1i1.3.

Aini, K. (2021). Analisis Proses Pembelajaran Daring pada Masa Pandemi Covid 19. Jurnal Studi Guru Dan Pembelajaran, 4(1). https://doi.org/10.30605/jsgp.4.1.2021.585.

Alami, Y. (2020). Media Pembelajaran Daring pada Masa Covid-19. Jurnal Pendidikan Agama Islam, 2(1), 49-56. https://ejournal.staisyamsululum.ac.id/index.php/jtt/article /view/71.

Anugrahana, A. (2020). Hambatan, Solusi dan Harapan: Pembelajaran Daring Selama Masa Pandemi Covid-19 oleh Guru Sekolah Dasar. Scholaria: Jurnal Pendidikan Dan Kebudayaan, 10(3), 282-289. https://doi.org/10.24246/j.js.2020.v10.i3.p282-289.

Asmuni, A. (2020). Problematika Pembelajaran Daring di Masa Pandemi Covid-19 dan Solusi Pemecahannya. Jurnal Paedagogy, 7(4), 281-288. https://doi.org/10.33394/jp.v7i4.2941.

Baharuddin, I. (2020). Pembelajaran Bermakna Berbasis Daring di tengah Pandemi Covid-19. Journal of Islamic Education Management, 1(2), 79-88. https://doi.org/10.24256/KELOLA.V5I2.1377.

Basri, H. (2018). Kemampuan Kognitif dalam Meningkatkan Efektivitas Pembelajaran Ilmu Sosial bagi Siswa Sekolah Dasar. Jurnal Penelitian Pendidikan, 18(1), 1-9. https://doi.org/10.17509/jpp.v18i1.11054.

Bujuri, D. A. (2018). Analisis Perkembangan Kognitif Anak Usia Dasar dan Implikasinya dalam Kegiatan Belajar Mengajar. Literasi (Jurnal Ilmu Pendidikan), 9(1), 37. https://doi.org/10.21927/literasi.2018.9(1).37-50.

Fathimah, N. S., \& Ishartiwi, I. (2018). Pengembangan Multimedia Mermainan Interaktif Pembelajaran Berhitung bagi Anak Diskalkulia Usia Prasekolah. Jurnal Inovasi Teknologi Pendidikan, 5(2), 115128. https://doi.org/10.21831/jitp.v5i2.15541.

Firdaus, F. Z., Suryanti, S., \& Azizah, U. (2020). Pengembangan Multimedia Interaktif Berbasis Pendekatan SETS untuk Meningkatkan Kemampuan Berpikir Kritis Siswa Sekolah Dasar. Jurnal Basicedu, 4(3), 681-689. https://doi.org/10.31004/basicedu.v4i3.417.

Harahap, S. A., Dimyati, D., \& Purwanta, E. (2021). Problematika Pembelajaran Daring dan Luring Anak Usia Dini bagi Guru dan Orang Tua di Masa Pandemi Covid 19. Jurnal Obsesi : Jurnal Pendidikan Anak Usia Dini, 5(2), 1825-1836. https://doi.org/10.31004/obsesi.v5i2.1013.

Husein, S., Herayanti, L., \& Gunawan, G. (2017). Pengaruh Penggunaan Multimedia Interaktif terhadap Penguasaan Konsep dan Keterampilan Berpikir Kritis Siswa pada Materi Suhu dan Kalor. Jurnal Pendidikan Fisika Dan Teknologi, 1(3), 221. https://doi.org/10.29303/jpft.v1i3.262.

Ichsan, I. Z., Iriani, E., \& Hermawati, F. M. (2018). Peningkatkan Keterampilan Berpikir Tingkat Tinggi (Higher Order Thinking Skills) pada Siswa Sekolah Dasar melalui Video Berbasis Kasus Pencemaran Lingkungan. Edubiotik: Jurnal Pendidikan, Biologi Dan Terapan, 3(02), 12-18. https://doi.org/10.33503/ebio.v3i02.175.

Khaulani, F., S, N., \& Irdamurni, I. (2020). Fase dan Tugas Perkembangan Anak Sekolah Dasar. Jurnal Ilmiah Pendidikan Dasar, 7(1), 51. https://doi.org/10.30659/pendas.7.1.51-59.

Kumalasani, M. P. (2018). Kepraktisan Penggunaan Multimedia Interaktif pada Pembelajaran Tematik Kelas IV SD. Jurnal Bidang Pendidikan Dasar, 2(1A), 1-11. https://doi.org/10.21067/jbpd.v2i1A.2345.

Kurniawati, I. D., \& Nita, S.-. (2018). Media Pembelajaran Berbasis Multimedia Interaktif untuk Meningkatkan Pemahaman Konsep Mahasiswa. DoubleClick: Journal of Computer and Information Technology, 1(2), 68. https://doi.org/10.25273/doubleclick.v1i2.1540.

Muin, A. (2017). Keterampilan Berbasis Multimedia Interaktif pada Pembelajaran Seni Budaya di Sekolah Dasar. Indonesian Journal Education Studies, 20(2). https://doi.org/10.26858/ijes.v20i2.4821.

Mustakim, M. (2020). Efektivitas Pembelajaran Daring Menggunakan Media Online Selama Pandemi Covid-19 pada Mata Pelajaran Matematika. Al Asma: Journal of Islamic Education, 2(1), 1. https://doi.org/10.24252/asma.v2i1.13646.

Nugraha, S. A., Sudiatmi, T., \& Suswandari, M. (2020). Studi Pengaruh Daring Learning terhadap Hasil Belajar Matematika Kelas IV. Jurnal Inovasi Penelitian, 1(3), 265-276. https://doi.org/10.47492/jip.v1i3.74. 
Nurhusain, M., \& Hadi, A. (2021). Desain Pembelajaran Statistika Terapan Berbasis Kasus Berkualitas Baik (Valid, Praktis, dan Efektif) untuk Mahasiswa Pendidikan Matematika. Indonesian Journal of Educational Science (IJES), 3(2), 105-119. https://doi.org/10.31605/ijes.v3i2.951.

Pancaningrum, E., \& Sari, D. K. (2020). Analisa Epic Model: Mengukur Efektivitas Iklan Indomie Versi Ayam Geprek di Televisi. Jurnal Research Manajemen Dan Bisnis Dewantara, 2(1). https://doi.org/10.26533/jmd.v2i1.444.

Panditung, A. R. (2020). Implementasi Kegiatan Pembelajaran Jarak Jauh Era Pandemi Covid-19 di Tingkat SMA. Jurnal Pendidikan Dan Pengajaran, 5(4). https://doi.org/10.32585/edudikara.v5i4.198.

Priyastuti, M. T., \& Suhadi, S. (2020). Kepuasaan Mahasiswa terhadap Pembelajaran Daring Selama Pandemi Covid-19. Journal of Language and Health, 1(2), 49-56. https: //doi.org/10.37287/jlh.v1i2.383.

Pujowati, Y. (2021). Dinamika Kebijakan Pembelajaran Daring di Era Pandemi Covid-19. Jurnal Pamator, 14(2). https://doi.org/https://doi.org/10.21107/pamator.v14i2.11574.

Salsabila, U. H., Sofia, M. N., \& Seviarica, H. P. (2020). Urgensi Penggunaan Media Audiovisual dalam Meningkatkan Motivasi Pembelajaran Daring di Sekolah Dasar. Insania: Jurnal Pemikiran Alternatif Kependidikan, 25(2), 284-304. https://doi.org/10.24090/insania.v25i2.4221.

Satrianingrum, A. P., \& Prasetyo, I. (2020). Persepsi Guru Dampak Pandemi Covid-19 terhadap Pelaksanaan Pembelajaran Daring di PAUD. Jurnal Obsesi : Jurnal Pendidikan Anak Usia Dini, 5(1), 633. https://doi.org/10.31004/obsesi.v5i1.574.

Subakti, H., \& Handayani, E. S. (2021). Analisis Keterampilan Mengajar Guru dalam Pembelajaran Bahasa Indonesia Daring pada Siswa Sekolah Dasar. Diglosia: Jurnal Pendidikan, 5(1), 202-210. http://jurnal.unma.ac.id/index.php/dl/article/view/2539.

Telaumbanua, Y. N. (2021). Pembelajaran Matematika secara Daring Akibat Pandemi Corona Virus Diseases 2019. Jurnal Review Pendidikan Dan Pengajaran, 3(2), 445-449. https://doi.org/10.31004/jrpp.v3i2.1692.

Wibawa, A. E. Y. (2021). Implementasi Platform Digital sebagai Media Pembelajaran Daring Di MI Muhammadiyah Pk Kartasura pada Masa Pandemi Covid-19. Berajah Journal, 1(2), 76-84. https: //doi.org/10.47353/bj.v1i2.15.

Widyatmojo, G., \& Muhtadi, A. (2017). Pengembangan Multimedia Pembelajaran Interaktif Berbentuk Game untuk Menstimulasi Aspek Kognitif dan Bahasa. Jurnal Inovasi Teknologi Pendidikan, 4(1), 38. https://doi.org/10.21831/jitp.v4i1.10194.

Yuniarni, D., Sari, R. P., \& Atiq, A. (2019). Pengembangan Multimedia Interaktif Video Senam Animasi Berbasis Budaya Khas Kalimantan Barat. Jurnal Obsesi : Jurnal Pendidikan Anak Usia Dini, 4(1), 290. https://doi.org/10.31004/obsesi.v4i1.331.

Yunitasari, R., \& Hanifah, U. (2020). Pengaruh Pembelajaran Daring terhadap Minat Belajar Siswa pada Masa COVID-19. Edukatif: Jurnal Ilmu Pendidikan, 2(3), 232-243. https://doi.org/10.31004/edukatif.v2i3.142. 